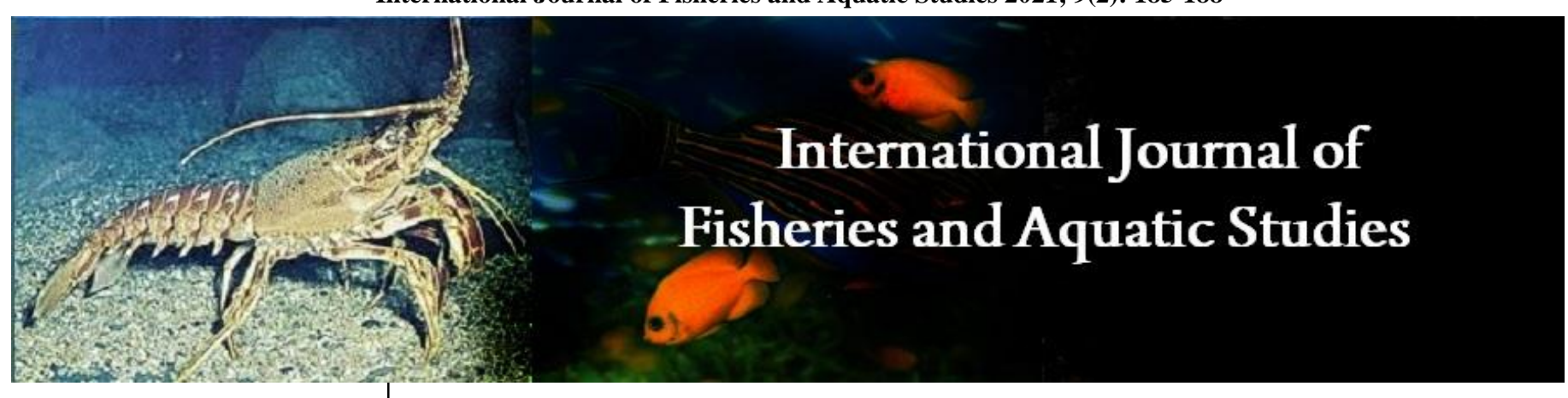

E-ISSN: 2347-5129

P-ISSN: 2394-0506

(ICV-Poland) Impact Value: 5.62

(GIF) Impact Factor: 0.549

IJFAS 2021; 9(2): 185-188

(C) 2021 IJFAS

www.fisheriesjournal.com

Received: 16-01-2021

Accepted: 19-02-2021

Pritiranjan Maiti

(1) Department of Chemistry,

Vidyasagar University,

Midnapore, West Bengal, India

(2) Coastal Ecology Research

Laboratory, Egra SSB College,

Purba Midnapore, West Bengal,

India

Amiya Kumar Panda

Department of Chemistry,

Vidyasagar University,

Midnapore, West Bengal, India

Sudipta Kumar Ghorai

Coastal Ecology Research

Laboratory, Egra SSB College,

Purba Midnapore, West Bengal,

India

Corresponding Author:

Sudipta Kumar Ghorai

Coastal Ecology Research

Laboratory, Egra SSB College,

Purba Midnapore, West Bengal,

India

\section{Mapping the wider impact of brackish water shrimp culture on the local environment and economy: A brief review}

\section{Pritiranjan Maiti, Amiya Kumar Panda and Sudipta Kumar Ghorai}

DOI: https://doi.org/10.22271/fish.2021.v9.i2c.2449

\begin{abstract}
Brackish water shrimp farming has changed the economic outlook of coastal areas of developing countries. Lucrative export opportunities, high profit margin compared to traditional aqua-culture and agriculture has led to an exponential growth of shrimp farming in the last decade.

Although, this new non-agricultural economic activity has been identified as a game-changer in the rural coastal areas, the associated criticism cannot be ignored. Several scientific studies have particularly pointed out the adverse impact of unscientific shrimp farming and its long term effect on the coastal biodiversity and environment. In the future and soon, the damage incurred can outweigh the benefit, leading to a potential irreversible downfall of local economy, food security and crop production.

In this article, we have made a concise effort to map the wider impact of brackish water shrimp farming and a possible way out and suggestion for future bettermen.
\end{abstract}

Keywords: wider impact, brackish water shrimp culture, environment, economy

\section{Introduction}

Modern civilization, throughout the globe, has flourished geographically on the coasts of sea, primarily due to the ease of livelihood requirements. The culture, habitat, food production and food consumptions also constantly vary from coastal to interior main lands of countries. One of the common food behaviors along the global coastline areas is the higher consumption of sea based foods, namely different varieties of sea-fishes and shrimps. With growing demand, different methods to increase the production of sea-foods have been adopted, which include larger quantities of fish harvest from costal sea by fishing boats and artificial production of fish and shrimp in sea like condition, i.e., brackish aquaculture. In recent decade, brackish water shrimp culture has boomed to meet global demand and has, in turn, changed the geographic and socio-economic structure of the coastal areas of South-East Asia having a near irreversible effect on the coastal population.

Here, we have briefly identified a small number of factors that are affected in this process, which we believe, are of outmost importance in the region.

\section{Biodiversity Loss Due To Brackish Water Shrimp Farming}

Loss of Mangrove Forests

Geographically, a large portion of the coastal areas of South-East Asia are the natural habitat of mangrove forests. Although, mangroves have traditionally been used for shrimp farming for decades, but with rapid expansion of commercial shrimp farming and consequent native forest clearance demanded by these systems, mangrove ecosystems are rapidly being lost. But it has been estimated that, over half of the world's original mangrove cover has been destroyed (Kelleher et al. 1995) ${ }^{[1]}$. Although, the national rates for the decline of mangrove cover differ state wise, but a dominant pattern for large mangrove forests exists for nearly every country (Valiela et al. 2001) ${ }^{[2]}$. Data from various studies also shows that, a significant portion of the destruction has occurred in recent decades (Spalding et al. 1997; World Resources Institute 2000-2001) ${ }^{[3,2]}$. A brief detail can be as follows: 
1. An estimated $83.7 \%$ loss of original mangroves in Thailand has happened since 1975 (MacKinnon 1997, Spalding et al. $1997^{[4,3]}$, World Resources Institute 2000-2001) ${ }^{[2]}$, and 35\% of the total area of has been lost in the last 20 years (Valiela et al. 2001) ${ }^{[2]}$. An estimation shows that, the rate of loss in Thailand could be as high as 6037 ha per year (Sathirathai and Barbier 2001) ${ }^{[5]}$.

2. World Bank, in 2002, has estimated that Vietnam has lost more than $80 \%$ of its mangrove forests over the last 50 years. Valiela et al. (2001) ${ }^{[2]}$ reported that, a total of $38 \%$ mangrove loss can be attributed to the conversion to shrimp aquaculture and shrimp culture is, by far, the greatest single cause of mangrove loss.

3. It has been estimated that, the mangrove forest in Bangladesh's Chokoria Sundarban forest fell to a merely 973 ha in 1988 from 7,500 ha in 1976, primarily due to shrimp farming and affected nearly $90 \%$ of the local community (Hossain et al. 2001) ${ }^{[6]}$.

4. In Philippines, nearly half of 279,000 ha of mangrove forests have been abolished within 1951-1988, and are converted into aquaculture ponds. Roughly, the $95 \%$ of all Philippine brackish water ponds have been derived from mangroves (Primavera 1995) ${ }^{[7]}$.

5. Around 269,000 ha of mangroves were reportedly converted to shrimp ponds in Indonesia between 1960 and 1990 (Harrison and Pearce 2000) ${ }^{[8]}$ and about 50\% of Nypa stands in Borneo's Mahakam River have been lost to aquaculture in the last 10 years (Blasco et al. 2001) ${ }^{[9]}$.

6. Over the last 20 years, nearly $50 \%$ of Ecuador's mangroves have been lost to shrimp farm development (Lacerda et al. 2002) ${ }^{[10,12]}$.

7. A recent report revealed that, due to shrimp farming in the Gulf of Fonseca, Honduras, about one third of dense mangroves was directly destructed. (DeWalt et al. 1996). The rate of loss of mangroves was alarmingly as high as $2,000-4,000$ ha per year, a rate that could be expected to lead to the total loss of all mangroves by 2020 (Lal 2002) [12].

Although, the required legislation for the protection of mangroves has been adopted by various states in recent years, the progress is very slow and as a direct consequence, the measures might be too late to implement for the survival of this fragile ecology.

\section{Impact On Costal Wetlands}

Apart from the loss of a vast portion of mangrove cover in the coastal areas, the brackish water shrimp farming has also caused negative impact on the other coastal wetlands. The sudden and exponential growth of shrimp farm has caused the transformation and degradation of other important wetland habitats, such as salt marshes, and even freshwater wetlands. For example,

- In Sri Lanka, the famous salt marshes of Puttalam / Mundal estuarine system, particularly the MiOya flood plains, have severely been threatened due to increased shrimp farming. Around half of MiOya basin's salt marshes and over 200 ha of salt marshes of Puttalam lagoon have been converted into shrimp farms. (Dayaratne et al. 1997) ${ }^{[13]}$.

- Vietnam's the Mekong Delta's extensive seasonal grasslands, and patches of Melaleuca forests are rapidly destroyed to form new brackish water shrimp farms.
(Tran Triet 2001).

- In Bangladesh, the decline of native freshwater prawn Macrobrachium rosenbergii, Indian bullfrog (Ranatigrina), the 'farmer's friend' and important freshwater snail Pilaglobosa have been directly linked to the rise of brackish water shrimp farming. (Ahmed 2001) [15].

\section{Wider Impact On Environment}

Significant secondary impact on environment has been resulted due to brackish water shrimp farming. These include salinization of soil, reduced water flow, unwanted salinization and depletion of ground and surface water supplies, reduction of wild fish and shrimp populations, and biological pollution of native shrimp stocks.

Environmental pollution has also emerged as one of the key issue for this unregulated farming. Due to excess use of pesticides, bleaches, and antibiotics in the shrimp-culture, organic and inorganic pollution has been increased which has detrimental effect on the health of the local environment as well as population (Shanahan and Trent 2003) ${ }^{[16]}$.

\section{Effect Of Shrimp Farming On The Food Security And Crop Production}

India is a growing nation in terms of population and currently ranks as second only to China. To properly feed and nourish this huge population, India has adopted relatively modern agriculture and food security measures. Especially, following the Green Revolution, the crop production has increased mainly due to the proper utilization of fertile lands, in presence modern fertilizer, in a multi-season way to attain its full potential. Incidentally, the lower Ganges-basin is one of the most fertile landmass in the earth, and with the suitable weather and rain fall, the high water intensive crops, i.e., rice, jute, vegetables can be easily and cost-effectively cultivated in this area. This creates a local self-reliance of food security as well as food-surplus advantage to this area, which leads to a self-sufficiency and lower retail pricing of the food products. High production of foods, also lead to higher trade and export and in turn, a higher economic gain for the region. So, at a high saturation of crop yielding scenario, the total crop production is proportional to the available agricultural land.

But the unscientific and exponential growth in the brackish water shrimp farming is a direct and irreversible threat to food security.

\section{Change In Traditional Agricultural Pattern}

The extensive conversion of agricultural lands to brackish water fisheries is leading to the decrease in available farmland. Often, these conversions are achieved in undocumented fashion, with private transfer of lands to large private shrimp firms bypassing the legal processes. This leads to the cease of proper understanding of the reality of land distribution map and survey of an area, which ultimately affects in the failure of the required policy implementation.

Shrimp farming in the areas, those are very close to sea coast, has a very negative impact on the overall agricultural land distribution. Traditionally, over the years a large part of costal land soil has been very expensively converted from high saline to agriculturally useful soil. Sudden change of the land character not only reverses all this efforts, but also converts the surrounding lands into infertile due to water leakage. This effect is more prominent, when traditional fertile lands are 
converted into shrimp ponds.

These land conversion also result in the change of livelihood of the residents of this areas. The small land owners, predominantly unskilled in aquaculture, often find themselves as the labor force in the newly created shrimp farms. Again, as shrimp farming is less labor intensive than agriculture (Barraclough and Finger-Stich 1996) ${ }^{[17]}$, an immediate crisis of job loss and unemployment occurs in the area.

The effect is similar to other agricultural products like fruits and vegetables. Any related ancillary activities, such as, grazing cattle, homestead gardening, local level food processing, fertilizer distribution, seed storage are also similarly affected.

\section{Larger Effect On Food Security}

A larger effect on the food security can be related to the disruption of non- agriculture based activities. Most prominent of this category is the reduction in local fresh water aquaculture of different fish species. It is to be noted that, the shrimp culture is mainly aimed at export to other countries, rather that local consumption. So, the loss of fresh water ponds results in a drastic drop in the fish production in this area. As a result, the demand supply balance is disrupted and therefore, the local economy and the local population suffer. All of this results in a larger economic and humanitarian effect on the local population. Local land owners and labors gets detached from the land and local food production decreases. As a result, livelihood dependency shifts from local food sustenance towards the market value of shrimp production and export. This larger market dependency for food pricing means that the local self-sufficiency and sustenance is disturbed.

\section{Impact Of Brackish Water Fisheries On Socio-Economic Development}

Brackish water shrimp farming has a significant role on the socio-economic development of coastal area. Inland brackish water fisheries are a provider of source of income, employment, necessary nutrients, engagement of rural and marginal workers, and livelihood for farmers. It makes a valuable achievement to social and economic development of this study area. Most of the peoples are engaged in fishing activities i.e. net weaving and repairing, fish feeding, distribution of small shrimp, reformation of water bodies (pond), import of feed and export of shrimp business etc.

The important contributions of this primary sector have been elaborated here and hopefully, it will help in socioeconomic development in this study area-

1. Necessary nutrient supply to our body (fat, iron, calcium, phosphorous etc.),

2. Protein supplement,

3. Source of income (national and international money),

4. High profitable farming,

5. More profits in less time,

6. Contribution of the local economy,

7. Alleviate poverty through employment generation,

8. Economic development,

9. Improve the standard of living,

10. Infrastructural development (construction of road, house, building of fish market etc.)

11. Establishment of training center,

12. Development of ancillary or secondary industry (ice factory, packaging industry, fish processing industry etc.)

13. Import of seeds and export of shrimp business
Analysis of the Problems for Increasing Brackish Water Fisheries and decreasing Agricultural Land

Inspite of the socio-economic development of this study area due to shrimp farming, many associated problems have emerged in the natural environment, such as,

1. Decreasing agricultural land,

2. Increase the salinity of soil,

3. Production of paddy and other crops are decreasing, which might result in shortage of food in near future.

4. The rich people are getting richer increasing the socioeconomic imbalance

5. A boom in illegal shrimp farming system,

6. Traditional cultivation firm workers are losing jobs, resulting in an increase in migration of labour force,

7. Increasing salinity leading to a reduced crop production which disproportionately affecting the poor farmers heavily and they are being forced to lease the land,

8. Often, due to local socio-political pressure, land owners are forced to lease the land,

9. Unrestricted use of antibiotics in shrimp firms,

10. Ecosystem is being interrupted,

11. As this shrimp is mainly exported, in local market shrimp deficit is going on,

12. Unconsciousness to fresh water fish farming for low profit,

13. Increasing shrimp disease due to attack of virus and bacteria.

14. Primary cost is much higher, so shrimp farming is not possible by poor farmers,

15. Lack of trained labours etc.

\section{Suggestions For Future Betterment}

For the apparent socio-economic development coastal area through shrimp farming, many man-made problems have been created which disrupted the balance of the natural environment. In this situation, the suggestions for future betterment are given below.

1. Permission from Government for brackish water shrimp farming,

2. Without permission no fishing pond can be created,

3. The Government should have to be stricter about giving permission,

4. To provide necessary training to the workers,

5. The use of antibiotic should be reduced,

6. Fresh water shrimp culture should be increased gradually,

7. Parallel methods to increase the income from different traditional crops should be arranged,

8. Different livelihoods should be arranged,

9. Must specify specific places for brackish water farming, where only this will be cultivated,

10. Brackish water firming should be avoided in the areas with fertile soils,

11. To increase awareness among the people,

12. The project to supply the equipment for fisheries (net, pipkin etc.),

13. Reformation of water bodies,

14. Regular testing of water and soil properties,

15. Banking and insurance system for the fishermen,

16. Inland brackish water fish production data will have to be collected from fishermen, which will help to take better policy decisions,

17. Providing training and credit for non-fish related source of income in order to maintain the diversity of livelihood 
of the people,

18. Establishment of Fisheries Resource Centers (FRCs) in this study area to provide technical support

\section{Survey To Access The Extend Of The Problem}

The idea of economic prosperity leads to a growing trend towards shrimp farming in coastal region. As a result, the cultivable land area is decreasing. A careful and thorough survey of a properly designated costal area will lead to identify the extent of the problem. The survey can be conducted in the following points:

1. To identify the different types of natural resource of this coastal area,

2. To examine how people utilized these natural resources,

3. To show the nature of socio-economic development,

4. To show how coastal landform have changed,

5. To show the decrease of agricultural land due to increase of inland fishery and saline water,

6. To identify why poor farmers lease their land.

7. To identify the causes of Environmental pollution, soil degradation and loss of Bio-diversity,

8. To identify why people leave other jobs or business and have been engaged in shrimp farming.

9. To prepare the suitable method for sustainable land use,

10. To give the suggestion for better utilization of land,

11. To show different land-use planning,

12. To show the life-style of the inhabitants etc.

The survey study can be performed on the basis of intensive visit of study area, extensive literature review, experimental documentary analysis and field observation to know the landuse pattern, socio-economic and socio-cultural condition of this study area. Reports of Geological Survey of India (GSOI) and recent research papers published in different regional, national and international journals and presented in different seminars could be very vital and helping tools to prepare this study.

\section{Conclusion}

There is no doubt that the introduction of brackish water shrimp farming in the coastal areas has impacted positively in economic terms on the local population. Shrimp farming is a lucrative business model and capable of earning a huge amount of foreign currency. This flow of wealth brings development and sustenance to the local community.

However, there is a dark cloud forming in the horizon, which can potentially and irreversibly wash out all the economic gains. Unscientific and exponential growth of shrimp farming has brought out its adverse environmental effect. It is high time to act on an urgent basis to rectify the problems and to implement a sustainable and scientific approach to the entire process. Failing this, there will be irreversible damage across the environment, economy and livelihood of the local population.

\section{References}

1. Kelleher G, Bleakley C, Wells S. A Global Representative System of Marine Protected Areas, World Bank, Washington 1995;III:147.

2. Valiela I, Bowen JL, York JK. Mangrove Forests: One of the World's Threatened Major Tropical Environments: At least $35 \%$ of the area of mangrove forests has been lost in the past two decades, losses that exceed those for tropical rain forests and coral reefs, two other well-known threatened environments, Bio Science 2001;51(10):807815.

3. Spalding M, Blasco F, Field C. World Mangrove Atlas.The International Society for Mangrove Ecosystems, Okinawa, Japan 1997, 178.

4. Mackinnon J. ed. Protected areas systems review of the Indo-Malayan realm. Asian Bureau for Conservation, Canterbury, UK 1997.

5. Sathirathai S, Barbie EB. Valuing Mangrove Conservation in Southern Thailand, Contemporary Economic Policy (Issn 1074-3529) 2001;19(2):109-122.

6. Hossain Md. S, Lin CK, Hussain MZ. Goodbye Chakaria Sunderban: The Oldest Mangrove Forest, Wetland Science and Practice 2001;18(3):19-22.

7. Primavera JH. Mangroves and brackish water pond culture in the Philippines. In: Wong YS., Tam N.F.Y. (eds) Asia-Pacific Symposium on Mangrove Ecosystems. Developments in Hydrobiology, Springer, Dordrecht 1995, 106.

8. Harrison P, Pearce F. The AAAS Atlas of Population and Environment. American Association for the Advancement of Science. University of California Press. Berkeley, California 2000.

9. Blasco F, Aizpuru M, Gers C. Depletion of the mangroves of Continental Asia. Wetlands Ecology and Management 2001;9:255-266

10. Lacerda LD, Conde JE, Kjerfve B, Alvarez-León R, Alarcón C, Polanía J. American Mangroves. In: de Lacerda L.D. (eds) Mangrove Ecosystems. Environmental Science. Springer, Berlin, Heidelberg 2002.

11. Chala Tamiru. Assessments impact of an invasive alien weed species on indigenous species and its management practices in eastern Hararghe, Ethiopia. Int. J Res. Agron. 2020;3(1):62-67.

12. Lal PN. Integrated and Adaptive Mangrove Management Framework - an Action Oriented Option for the New Millennium. In: de Lacerda L.D. (eds) Mangrove Ecosystems. Environmental Science. Springer, Berlin, Heidelberg 2002.

13. Dayaratne P. Review of the small pelagic fisheries of Sri Lanka, In Devaraj, M., and P. Martosubroto (eds). Small pelagic resources and their fisheries in the Asia-Pacific region: proceedings of the APFIC Workshop 1997, 300336.

14. Huu H, Paul N, Patrick D, Ammar M, Aziz A. Land-use change and socio-ecological drivers of wetland conversion in Ha Tien Plain, Mekong Delta, Vietnam, ISSN: 0264-8377 2017;64:101-113.

15. Ahmed N. Socio-economic aspects of freshwater prawn culture development in Bangladesh. PhD Thesis, Institute of Aquaculture, University of Stirling, Scotland, UK 2001.

16. Shanahan M, Trent S. Chemical crustaceans-pesticides and prawn farming. Pesticides News 2003.

17. Barraclough S, Finger-Stich A. Some ecological and social implications of commercial shrimp farming in Asia. UNRISD Discussion Paper 74. United Nations Research Institute for Social Development, Geneva, and World Wide Fund for Nature-International, Gland, Switzerland, 1996, 62.

18. Shrimp aquaculture development and the environment: People, mangroves and fisheries on the Gulf of Fonseca, Honduras, ISSN: 0305-750X, 1996;24(7):1193-1208. 